\title{
Viral-Induced Myocarditis in Patient with Anomalous Origin of the Left Circumflex Artery from the Right Coronary Artery.
}

Keywords:

Posted Date: October 25th, 2021

DOI: https://doi.org/10.21203/rs.3.rs-1017127/v1

License: (c) (1) This work is licensed under a Creative Commons Attribution 4.0 International License. Read Full License 


\section{Abstract}

The authors have requested that this preprint be removed from Research Square. 